Eur. J. Clin. Chem. Clin. Biochem.

Vol. 31, 1993, pp. $441-446$

(C) 1993 Walter de Gruyter \& Co.

Berlin - New York

\title{
Development of an Amplified Enzyme-Linked Immunosorbent Assay for Sensitive Measurement of Apolipoprotein B in Plasma and Tissue Culture Media ${ }^{1}$
}

\author{
By J. Macri and K. Adeli
}

Division of Clinical Chemistry, Department of Chemistry and Biochemistry, University of Windsor, Windsor, Ontario. Canada

(Received January 4/February 26, 1993)

Summary: We have developed a non-competitive sandwich enzyme-linked immunosorbent assay for the quantitation of apolipoprotein B, which utilizes the biotin-avidin amplification system. All components were optimized with respect to either concentration or incubation time. The assay uses microtitre wells as a solid phase and polyclonal, affinity-purified capture antibody. The amplification system was composed of hydroxysuccinimide biotin conjugated to an affinity-purified anti-apolipoprotein B IgG and either ExtrAvidin-alkaline phosphatase or streptavidin-alkaline phosphatase. The within-run precision $(n=10)$ of the apolipoprotein $B$ control $(1.39 \mathrm{~g} / \mathrm{l})$ was $3 \%$, while the between-run precision of the assay $(\mathrm{n}=6)$ for 9 consecutive assays was determined to be $8 \%$. A sensitivity of $3 \mathrm{ng}$ was attained, with a mean analytical recovery of $110 \%$. Comparison of the assay with an established immunoturbidometric method resulted in a correlation of 0.92 using patient plasma samples $(\mathrm{n}=19)$. The use of the biotin-avidin amplification system provides the sensitivity required for measuring apolipoprotein $B$ in tissue culture media samples and circumvents the many problems associated with the direct conjugation of enzymes to antibodies. Minimal amounts of reagents are required and the assay can be performed in $5 \mathrm{~h}$, making it both economical and practical for clinical laboratories.

\section{Introduction}

Apolipoprotein B is the major protein component of very low density lipoprotein (VLDL) and low density lipoprotein (LDL) in humans. It is a structural protein that allows lipids to be transported in the aqueous plasma environment. In addition, apolipoprotein B binds to cell surface receptors and facilitates incorporation of lipoproteins into peripheral tissues and organs. Increasing attention is being paid to determinating apolipoprotein B concentrations in plasma, due to evidence suggesting its usefulness in diagnosing and characterizing various types of dyslipidaemias (1). Measuring apolipoprotein B concentration may also be useful in determining the severity of coronary heart disease (2) and in predicting the risk of its development (3).

1) This work was supported by a research grant from the Heart and Stroke Foundation of Ontario (AN 1901).
A considerable number of methods have been utilized to quantitate plasma apolipoprotein B concentrations. The majority of these assays are immunological techniques such as immunonephelometry $(4,5)$, radioimmunoassay (RIA) $(6,7)$ and enzyme immunoassay (EIA) $(8,9)$. While immunonephelometric assays are fast and accurate, their sensitivity to the turbidity of the sample and the requirement of the use of enzymes or detergents with hypertriglyceridaemic samples are definite drawbacks (10). RIAs developed for the determination of apolipoprotein B concentrations show good accuracy and sensitivity, but have several disadvantages, such as expensive reagents and the use of radioisotopes $(10,11)$. Quantitation of apolipoprotein B by EIAs such as enzymelinked immunosorbent assay (ELISA) gives results that are reproducible, accurate, and with a sensitivity comparable to that of RIAs (10). This is accomplished without the use of radioisotopes as in RIAs, and 
without interference from sample turbidity as in immunoturbidometric methods. A few direct ELISA assays have been developed for plasma apolipoprotein $\mathrm{B}$ determinations $(12-16)$. The major drawback with these assays is the direct conjugation of apolipoprotein $\mathrm{B}$ antibody to an enzyme using harsh crosslinkers such as glutaraldehyde or periodate which have a potential for causing changes in antibody-antigen binding, resulting in lower enzyme activity (17).

We have developed a non-competitive sandwich ELISA for the measurement of apolipoprotein B concentrations utilizing the biotin-avidin amplification system. The use of the biotin-avidin system circumvents the above problem with enzyme-antibody conjugation by using a biotinylated antibody that can be prepared under mild and non-denaturing conditions. In addition, the assay uses minimal amounts of reagents and can be performed in a normal working day, making it both economical and practical for clinical laboratories. Further, the high sensitivity of the assay allows it to be applied to in vitro cell-culture studies where apolipoprotein B concentrations are extremely low.

\section{Materials and Methods}

\section{Blood and media samples}

Blood was drawn at either Windsor Western Hospital or The Windsor Red Cross from healthy donors by venipuncture into EDTA-vacutainer tubes. The plasma was separated and stored at $-20^{\circ} \mathrm{C}$. Media samples containing secreted proteins were collected from cultures of human hepatoma cells (HepG2), centrifuged to remove any cellular debris and then stored at $-20^{\circ} \mathrm{C}$. A cocktail of protease inhibitors $(1 \mathrm{mmol} / \mathrm{l}$ benzamidine, $5 \mathrm{mmol} / 1$ EDTA, $0.86 \mathrm{mmol} / \mathrm{l}$ phenyl methyl sulphonyl fluoride, $100 \cdot 10^{3} \mathrm{KIU} / \mathrm{l}$ of aprotinin, $10 \mathrm{mmol} / \mathrm{l}$ Hepes, 50 $\mathrm{mg} / \mathrm{l}$ leupeptin, $50 \mathrm{mg} / \mathrm{l}$ pepstatin A) was added to all samples immediately following their collection in order to prevent apolipoprotein B degradation.

\section{Apolipoprotein B standards and control}

The apolipoprotein B standards and control (Atlantic Antibodies, Scarborough, Maine) were diluted in phosphate buffered saline containing $5 \mathrm{~g} / \mathrm{l}$ bovine serum albumin and $0.5 \mathrm{ml}$ per litre Tween-20. The concentrations of the standards and control (Atlantic Antibodies) used in both the immunoturbidometric and ELISA methods were based on a CDC reference material (IUIS-WHO Apo-AI and B serum reference material) from the CDC, Atlanta GA. Both the ELISA and the immunoturbidometric assays were calibrated with the same standards, which were in turn standardized based on the CDC reference material. The accuracy of the two methods was further examined by running a commercial control material, the value of which was also assigned based on the $C D C$ reference material.

\section{Apolipoprotein B antibody}

The apolipoprotein B antibody used in this assay was an affinity-purified IgG fraction obtained from Medix Biotech Inc, Foster City CA. This preparation was thoroughly characterized by western-blotting of both plasma and media samples. The antibody was determined to be reactive with both apolipoprotein B-100 and apolipoprotein B-48. No cross-reactivity was observed between the antibody and other apolipoproteins based on immunoblotting of whole plasma' and HepG2 culture media (data not shown).

\section{Apolipoprotein B antibody-biotin conjugate}

The biotinylation of the apolipoprotein B antibody was conducted using a modification of a procedure by Bayer \& Wilchek (18). A solution of $0.5 \mathrm{mg}$ apolipoprotein B antibody and 500 $\mu$ l sodium borate buffer $(0.1 \mathrm{~mol} / 1 \mathrm{pH} 8.8)$ was prepared. The solution was dialyzed for $16 \mathrm{~h}$ at $4^{\circ} \mathrm{C}$ against the borate buffer to remove sodium azide. A solution of $1 \mathrm{mg} \mathrm{N}$-hydroxysuccinimide biotin (Sigma Chemical Co., St. Louis MO) in $100 \mu l$ dimethyl sulphoxide was prepared. A total of $250 \mu \mathrm{g}$ of the biotin ester was added with continuous mixing to the antibody solution. Such a ratio of ester to antibody resulted in a high probability that all the antibodies were biotinylated. The solution was incubated for $2 \mathrm{~h}$ in the dark at room temperature. The antibody-biotin conjugate was then treated with $50 \mu$ of $1 \mathrm{~mol} / 1 \mathrm{NH}_{4} \mathrm{Cl}$ for $10 \mathrm{~min}$ at room temperature. The preparation was then dialyzed against phosphate buffered saline for $36 \mathrm{~h}$ to remove unbound biotin. Following dialysis, the antibody-biotin conjugate was stored at $4{ }^{\circ} \mathrm{C}$ and was stable for 3 months. The biotinylation procedure resulted in a molar ratio of ester to antibody of more than $10: 1$. The antibody-biotin conjugate working solution was prepared by dilution in 10 mmol/1 Tris $\mathrm{pH} 7.8$ containing $3 \mathrm{~g} / \mathrm{l}$ bovine serum albumin and $0.4 \mathrm{~mol} / 1 \mathrm{KCl}$.

\section{Enzyme conjugate solution}

Either ExtrAvidin-alkaline phosphatase ${ }^{2}$ ) (Sigma) or streptavidin-alkaline phosphatase (Zymed Laboratories, San Francisco CA) were diluted in Tris $0.1 \mathrm{~mol} / \mathrm{l} \mathrm{pH} 8$ containing $0.5 \mathrm{mmol} / \mathrm{l}$ $\mathrm{MgCl}_{2}$.

\section{Substrate solution}

Nitrophenyl-phosphate (BDH, Toronto), at a concentration of $4 \mathrm{~g} / \mathrm{l}$, was dissolved in $1 \mathrm{~mol} / \mathrm{l}$ diethanolamine $\mathrm{pH} 9.8$ containing $0.5 \mathrm{mmol} / 1 \mathrm{MgCl}_{2}$.

\section{Coating procedure}

Microtitre 8 well strips (Costar, Cambridge MA) were coated with affinity-purified apolipoprotein $\mathrm{B}$ antibody that was diluted in $50 \mathrm{mmol} / \mathrm{l}$ carbonate buffer, $\mathrm{pH} \mathrm{9.6.} \mathrm{A} \mathrm{volume} \mathrm{of} 100$ $\mu l$ of the carbonate buffer containing $2 \mathrm{mg} / \mathrm{l}$ of the antibody was added into each well. The strips were covered and incubated overnight at $4{ }^{\circ} \mathrm{C}$. After the incubation period, the antibody solution was aspirated and washed 3 times consecutively with phosphate buffered saline containing $0.5 \mathrm{ml}$ per litre Tween-20 using an ELISA plate washer (a Corning 8 channel washer was used in this work). A solution containing $10 \mathrm{~g} / \mathrm{l}$ bovine serum albumin in $250 \mu \mathrm{l}$ aliquots was dispensed into each well for $1 \mathrm{~h}$ at room temperature to block any unbound sites. Following this period, washing was performed 3 times.

\section{Assay procedure}

Hundred $\mu \mathrm{l}$ of either standard, control or serum that had been diluted 1500 -fold were added to the wells. Media samples were added to the wells without diluting: After incubating for $2 \mathrm{~h}$ at

$\left.{ }^{2}\right)$ Enzyme: Alkaline phosphatase, Phosphoric monoester phosphohydrolase [alkaline optimum]: EC 3.1.3.1. 
room temperature the solutions was removed and washed with phosphate buffered saline-Tween, as above. The antibody-biotin solution was dispensed in volumes of $100 \mu \mathrm{l}$ per well for $1 \mathrm{~h}$ at room temperature. Washing was performed to remove any unbound antibody-biotin conjugate. A $100 \mu$ solution of the enzyme-conjugate containing either ExtrAvidin-alkaline phosphatase or streptavidin-alkaline phosphatase was added to each well for $1 \mathrm{~h}$ at room temperature. After washing, $100 \mu \mathrm{l}$ of the substrate solution was added to each well. The reaction was stopped by the addition of $100 \mu \mathrm{l}$ of $0.3 \mathrm{~mol} / \mathrm{l} \mathrm{NaOH}$ and the absorbances read at $405 \mathrm{~nm}$ using a microplate reader (in this study a Hyperion Micro Reader III, Hyperion Inc. Miami FL, was used).

\section{Results}

\section{Optimized assay conditions}

We optimized the concentration of the apolipoprotein $B$ antibody-biotin conjugate for use with two different commercial preparations of the enzyme conjugate. The biotinylated antibody was diluted in the range 25-fold to 390625 -fold when using ExtrAvidin-alkaline phosphatase or 50-fold to 78125 -fold when using streptavidin-alkaline phosphatase conjugate (fig. 1). The concentration of apolipoprotein B was kept constant $(1.34 \mathrm{~g} / \mathrm{l})$ and the assay carried out as described above. The optimal dilution for the biotinylated antibody was found to be 80 -fold when used with ExtrAvidin-alkaline phosphatase and 200-fold when used with streptavidin alkaline phosphatase.

The dilution of the enzyme conjugate was also optimized for both ExtrAvidin alkaline phosphatase and streptavidin alkaline phosphatase (fig. 2). The optimal dilution determined for both enzyme conjugates was 1000 -fold.

The final optimization involved determining the optimal substrate incubation time (that which resulted in a standard curve with the highest degree of linearity) for the assay. The assay was performed under
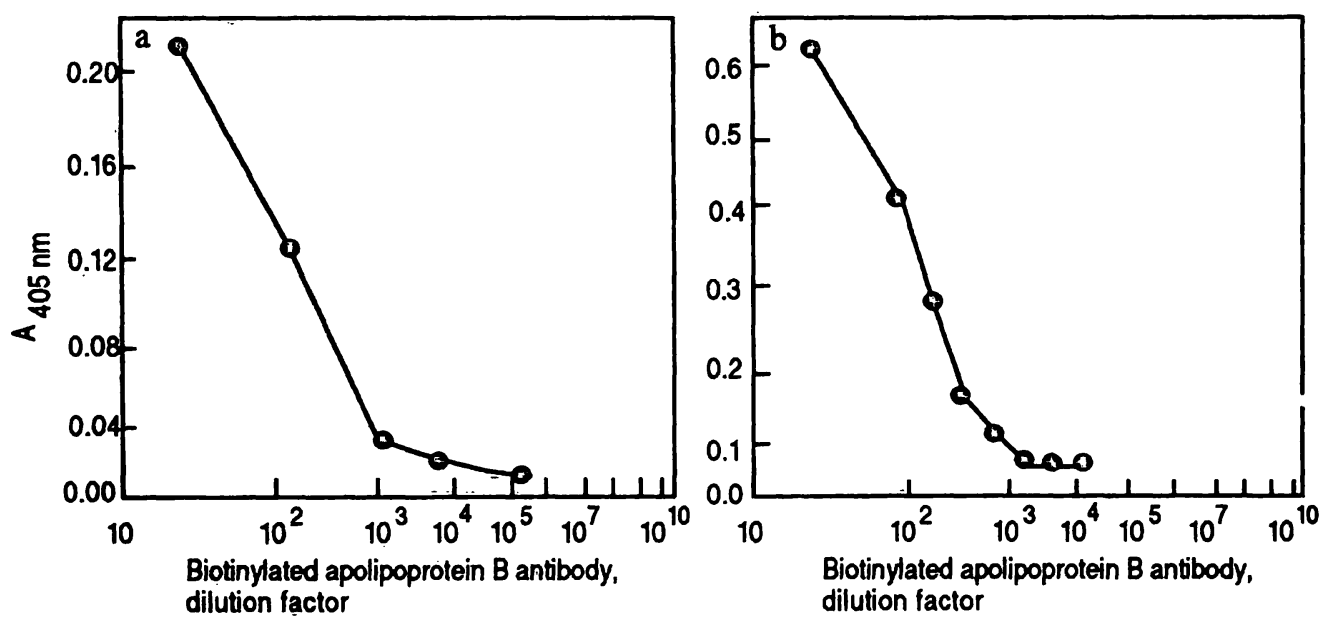

Fig. 1. Optimization of biotinylated apolipoprotein B antibody. Apolipoprotein B ELISA was performed with various dilutions of the biotinylated antibody using two preparations of enzyme conjugates, ExtrAvidin alkaline phosphatase (Sigma) (a) and streptavidin alkaline phosphatase (Zymed) (b).
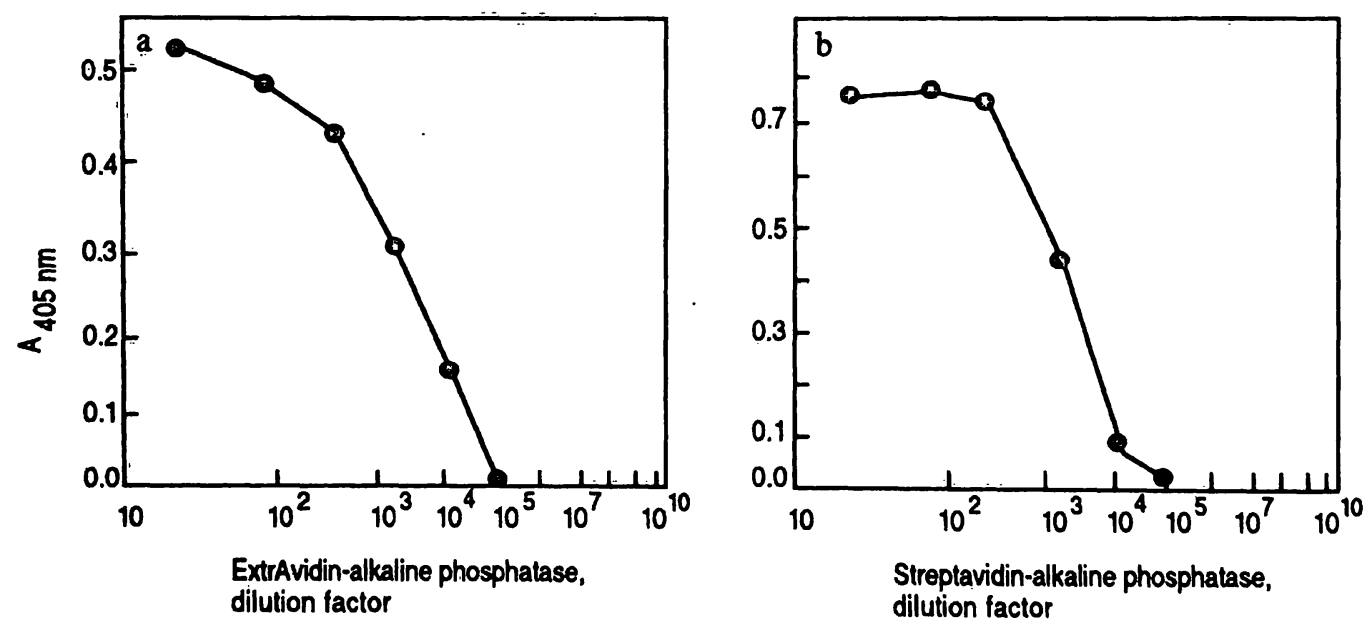

Fig. 2. Optimization of enżyme-avidin conjugates. Apolipoprotein B ELISA was performed with various dilutions of ExtrAvidin alkaline phosphatase (a) and streptavidin alkaline phosphatase (b). 

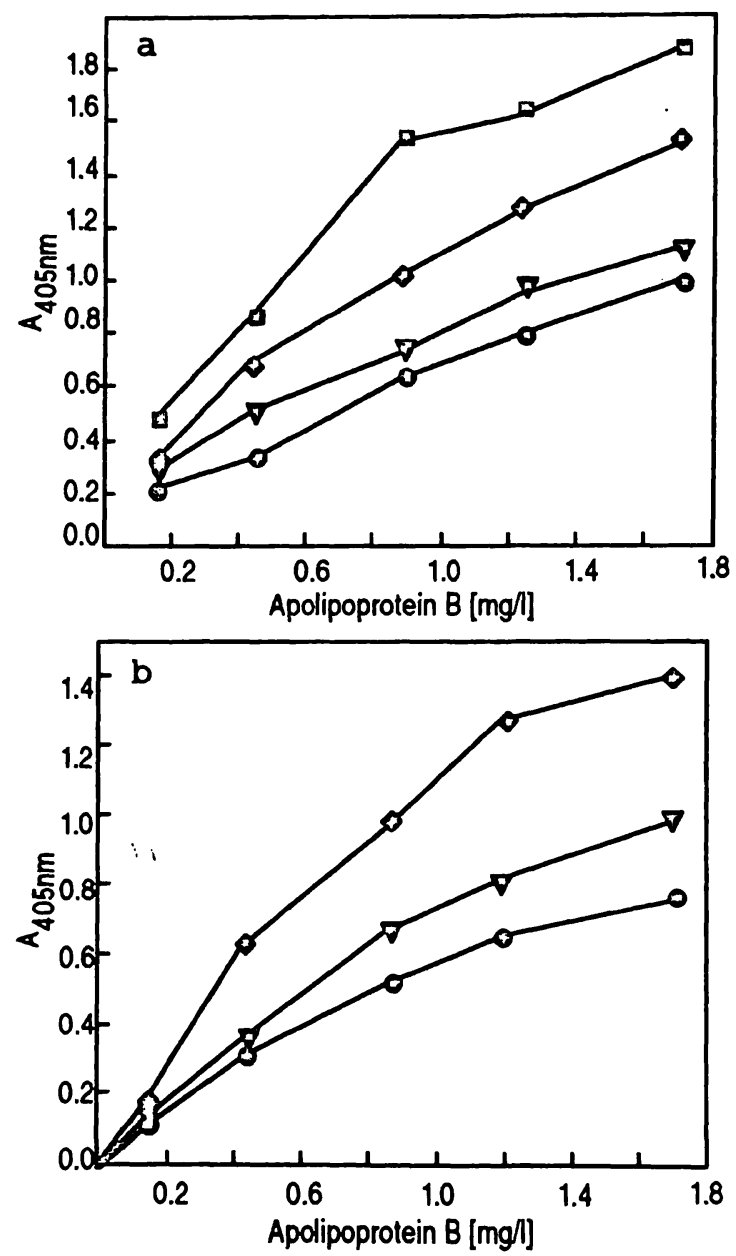

Fig. 3. Optimization of the substrate incubation time. Apolipoprotein B ELISA was performed with different substrate incubation times using either ExtrAvidin alkaline phosphatase (a) or streptavidin alkaline phosphatase (b). $5 \mathrm{~min}(\mathbf{0}), 7 \mathrm{~min}(\Delta), 10 \mathrm{~min}(\bullet), 15 \mathrm{~min}(\boldsymbol{a})$.

conditions in which both the antibody-biotin conjugate and the enzyme-conjugates had been optimized. The incubation time of the substrate was varied (5-15 min) using either ExtrAvidin alkaline phosphatase (fig. 3A) or streptavidin alkaline phosphatase (fig. 3B). The optimal incubation time was determined to be $5 \mathrm{~min}$ using ExtrAvidin alkaline phosphatase and $7 \mathrm{~min}$ using streptavidin alkaline phosphatase.

Figure 4 depicts the typical standard curves achieved using the optimized conditions (Dilutions: standards 1500 -fold, biotinylated antibody 80 or 200 -fold, enzyme conjugate 1000 -fold, substrate time 5 or $7 \mathrm{~min}$ ). An $r$ value of 0.99 was consistently observed for the standard curves. Comparisons of 3 typical standard curves indicated a variation of $4-8 \%$ between corresponding data points.

\section{Sensitivity and precision of the assay}

The sensitivity, based on 2.5 times the standard deviation of the zero standard $(n=5)$ was determined to be $3 \mathrm{ng}$, with a working range of $18-180 \mathrm{ng}$. The

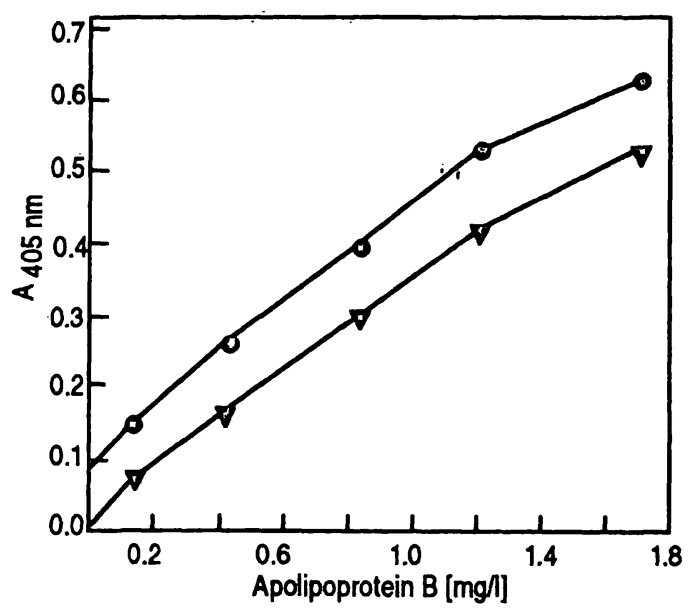

Fig. 4. Representative standard curves obtained following optimization of the assay components:

assay conducted with ExtrAvidin alkaline phosphatase as the enzyme-conjugate ( $(0)$;

assay conducted with streptavidin alkaline phosphatase as the enzyme conjugate $(\boldsymbol{\nabla})$.

within-run precision (CV), estimated by replicate analysis $(\mathrm{n}=10)$ of an apolipoprotein B control (1.39 $\mathrm{g} / \mathrm{l})$ was $3 \%$. The between-run precision of the assay was estimated by measuring the apolipoprotein B control $(n=6)$ in 9 assays run over a 5-day period. The between-run precision was determined to be $8 \%$ at a concentration of $1.39 \mathrm{~g} / \mathrm{l}$. The assay was routinely used to measure apolipoprotein $\mathrm{B}$ concentrations in HepG2 media under control and hormonal conditions such as insulin and triiodothyronine (19). Culture media concentrations of 0.16 to $1.80 \mathrm{mg} / \mathrm{l}$ were measured directly without having to concentrate the sample. Media samples often required a 2-4-fold dilution. Using media samples, the within-run precision was $5 \%$, based on replicate analysis $(n=5)$ of two media samples at concentrations of 1.88 and 1.10 $\mathrm{mg} / \mathrm{l}$.

\section{Accuracy}

A dilution experiment was conducted in order to estimate the recovery of apolipoprotein $B$ from a dilution series. Such a procedure has been utilized to estimate indirectly the accuray of immunoassays (20). A plasma-based apolipoprotein B was diluted 1.5 to 12-fold, and apolipoprotein B ELISA was performed on the diluted samples. The mean recovery of apolipoprotein B from the dilution series was $110 \%$ (tab. 1).

Comparison with an immunoturbidometric method

Results of the assay were compared with those of an established immunoturbidometric method on COBAS 
Tab. 1. Recovery of apolipoprotein B from a sample of apolipoprotein B diluted in sample buffer

\begin{tabular}{llll}
\hline Dilution & \multicolumn{2}{l}{ Apolipoprotein $\mathrm{B}$} & $\begin{array}{l}\text { Recovery } \\
(\%)\end{array}$ \\
\cline { 2 - 3 } & $\begin{array}{l}\text { expected } \\
(\mathrm{g} / \mathrm{l})\end{array}$ & $\begin{array}{l}\text { measured } \\
(\mathrm{g} / \mathrm{l})\end{array}$ & \\
\hline None & - & 1.457 & - \\
$1: 1.5$ & 0.971 & 0.875 & 90 \\
$1: 2$ & 0.728 & 0.715 & 98 \\
$1: 3$ & 0.485 & 0.515 & 106 \\
$1: 4$ & 0.364 & 0.442 & 120 \\
$1: 8$ & 0.182 & 0.217 & 119 \\
$1: 12$ & 0.121 & 0.165 & 136 \\
& & Mean & 110 \\
\hline
\end{tabular}

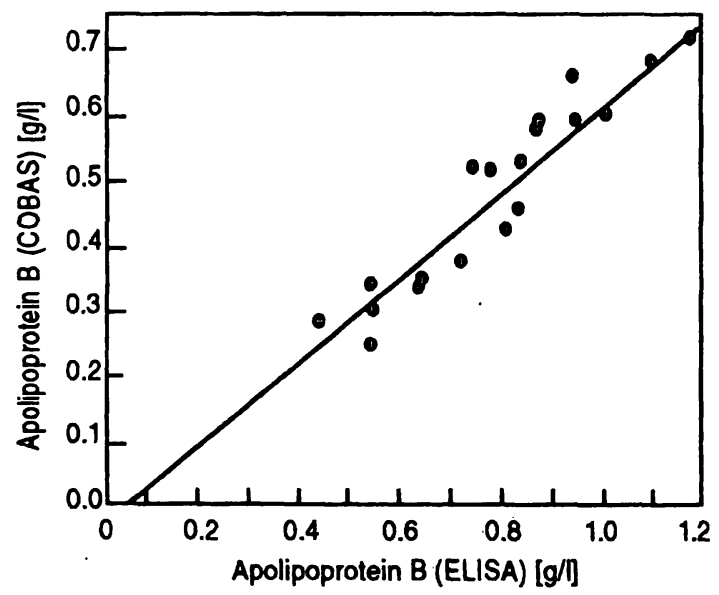

Fig. 5. Correlation between the biotin-avidin amplified ELISA and an immunoturbidimetric method on COBASFARA for the quantitation of apolipoprotein $B$.

FARA. Comparison resulted in a correlation of 0.92 with a slope of 1.48 and a y-intercept of -0.04 using sera samples $(n=19)$ that had been diluted 1500 fold (fig. 5).

\section{Discussion}

The use of a non-competitive ELISA for the assay of apolipoprotein B offers several advantages over a number of other assays used to quantitate apolipoprotein B. It does not require that the particle size of the antigen in the standards and samples be comparable as is the case with several immunoprecipitin assays. In addition, our assay is suitable both for media and all types of sera (e.g. dyslipoproteinaemic sera), since it is not interfered with by turbidity. The assay can also be easily adapted to an automation procedure, unlike radial immunodiffusion and electroimmunoassay techniques. Finally, it avoids the use of radioisotopes, which in a clinical environment poses a number of problems including special training for staff in the handling and disposal of radioactive material.
The precision and sensitivity of the present assay are comparable to the radioimmunoassays used to measure apolipoprotein B (10). In addition, when compared to other ELISAs the current method has a sensitivity and precision comparable to or greater than those assays reported to date $(10,13,15,21)$. A non-competitive ELISA developed by James et al. (1985) to quantitate apolipoprotein B reported a sensitivity of $2.5 \mathrm{ng}$ per assay with a working range of $10-100 \mathrm{ng}$. We report a sensitivity of $3 \mathrm{ng}$ per assay with a working range of $18-180 \mathrm{ng}$. In addition, the $5 \mathrm{~h}$ required to perform this assay is an improvement over several other ELISAs that cannot be easily performed in a normal working day $(8,13,15)$.

The current method compared well with an immunoturbidimetric method on an automated analyzer, but a significant bias was observed between the two methods. This discrepancy in the amount of antigen detected may result from the ELISA procedure; detecting a higher number of antigen molecules present in the sample than that detected by the immunoturbidometric method. Since the sample is diluted considerably in the ELISA method, more antigens may become available for antibody recognition.

The high degree of sensitivity afforded by the use of the biotin-avidin amplification system allows media samples to be assayed directly, without the need for concentrating the samples. The ELISA described here has a sensitivity comparable to that of radioimmunoassay methods commonly used to measure media apolipoprotein B concentrations. In addition, the use of biotinylated antibody avoids the need for conjugating apolipoprotein B antibody to an enzyme. Direct conjugation of antibody to enzymes has a number of drawbacks which are avoided in our assay. The high sensitivity of this assay requires that the standards and sera samples must be diluted considerably in order to be measured. Such high dilution factors have the potential for introducing considerable errors. This does not appear to be a significant problem with our assay as the within-run precision of the assay performed manually was less than $5 \%$. Automating the dilution of standards and samples should reduce this acceptable imprecision even further.

The assay performed well using either of the two commercial preparations of enzyme-avidin conjugates. However, it was possible to use the streptavidin alkaline phosphatase conjugate with a higher dilution of the biotinylated antibody, resulting in the use of less reagent per assay. The use of streptavidin alkaline phosphatase appeared also to result in standard curves with lower intercepts, suggesting decreased non-specific binding with this reagent. We are cur- 
rently adapting this non-competitive assay to quantitate other apolipoproteins such as apolipoprotein A-I and E.

\section{References}

1. Herbert, P. N., Assmann, G., Gotto, A. M. \& Fredrickson, D. S. (1983) Familial lipoprotein deficiency: Abetalipoproteinemia, hypobetalipoproteinemia, and Tangier disease. In: The Metabolic Basis of Inherited Disease, 5th edn. (Stanbury, J. B., Wyngaarden, J. B., Fredrickson, D. S., Goldstein, J. L. \& Brown, M. S., eds.) pp. 589-621, McGrawHill, New York.

2. Sedlis, S. P., Schechtman, K. B., Ludbrook, P. A., Sobel, B. E. \& Schonfeld, G. (1986) Plasma apoproteins and the severity of coronary artery disease. Circulation 73, 978986.

3. Freedman, D. S., Srinivasan, S. R., Shear, C. L., Franklin, F. A., Webber, L. S. \& Berenson, G. S. (1986) The relation of apolipoproteins AI and B in children to parental myocardial infarction. N. Engl. J. Med. 315, 712-716.

4. Ballantyne, F. C., Williamson, J., Shapiro, D., Caslake, M. J. \& Perry, B. (1978) Estimation of apolipoprotein in man by immunonephelometry. Clin. Chem. 24, 788-792.

5. Fievet-Desreumaux, C., Dedonder-Decoopman, E., Fruchart, J. C., Dewailly, P. \& Seizille, G. (1979) Immunochemical determination of human apolipoprotein B by laser nephelometry. Clin. Chim. Acta 95, 405-408.

6. Bedford, D. K., Shephard, J. \& Morgan, H. G. (1976) Radioimmunoassay for human plasma apolipoprotein B. Clin. Chim. Acta 70, 267-276.

7. Maynard, Y., Roden, D. C., Tikkanen, M. J., Schonfeld, G. \& Ladenson, J. H. (1984) Radioimmunoassay of apolipoprotein B with use of monoclonal antibodies. Clin. Chem. 30, 1620-1624.

8. Marcovina, S., France, D., Phillips, R. A. \& Mao, S. J. T. (1985) Monoclonal antibodies can precipitate low density lipoprotein. I. Characterization and use in determining apolipoprotein B. Clin. Chim. 31, 1654-1658.

9. Riesen, W. F., Sturzenegger, E., Imhof, C. \& Mordasini, R. (1986) Quantitation of apolipoprotein B by polyclonal and monoclonal antibodies. Clin. Chim. Acta 154, 29-40.

10. Labeur, C., Shepherd, J. \& Rosseneu, M. (1990) Immunological assays of apolipoproteins in plasma: Methods and instrumentation. Clin. Chem. 36, 591-597.

11. Bury, J. \& Rosseneu, M. (1988) Apolipoprotein quantitation by ELISA: Technical aspects and clinical applications. Rev. Immunoassay Tech. $1,1-25$.

\section{Acknowledgement}

We would like to thank Mr. Godwin Ogbonna for assisting us in performing the apolipoprotein B assays on Cobas Fara.

. 1

12. Fievet, C., Koffigan, M., Ouvry, D., Marcovina, S., Moschetto, Y. \& Fruchart, J. C. (1984) Noncompetitive enzymelinked immunoassay for apolipoprotein B in serum. Clin. Chem. 30, 98-100.

13. Fruchart, J. C., Desreumaux, C., Dewailly, P., Seille, G., Jaillard, J., Carlier, Y., Bout, D. \& Capron, A. (1978) Enzyme immunosassay for human apolipoprotein B, the major protein moiety in low-density and very-low-density lipoproteins. Clin. Chem. 24, 455-459.

14. Holmquist, L. (1982) Quantitation of human serum apolipoprotein B by enzyme immunoassay. Clin. Chim. Acta $121,327-336$.

15. Ordovas, J. M., Peterson, J. P., Santaniello, P., Cohn, J. S., Wilson, P. W. F. \& Schaefer, E. J. (1987) Enzyme linked immunosorbent assay for human plasma apolipoprotein B. J. Lipid. Res. 28, 1216-1224.

16. Young, S. G., Smith, R. S., Hogle, D. M., Curtiss, L. M. K. \& Witztum, J. L. (1986) Two new monoclonal antibody based enzyme-linked assays of apolipoprotein B. Clin. Chem. 32, 1484-1490.

17. O'Sullivan, M. J. \& Marks, V. (1981) Methods for the preparation of enzyme-antibody conjugates for the use in enzyme immunoassay. Methods. Enzymol. 73, 147-166.

18. Bayer, E. A. \& Wilchek, M. (1980) The use of avidin-biotin complex as a tool in molecular biology. Methods Biochem. Anal. 26, 1-45.

19. Theriault, A., Ogbonna, G. \& Adeli, K. (1992) Thyroid hormone modulates apolipoprotein $\mathrm{B}$ gene expression in HepG2 Cells. Biochem. Biophys. Res. Commun. 186, 617623.

20. Dhahir, F. J., Cook, D. B. \& Self, C. H. (1992) Amplified enzyme-linked immunoassay of human proinsulin in serum (detection limit: $0.1 \mathrm{pmol} / \mathrm{l}$ ). Clin. Chem. 38, 227-232.

21. James, R. W., Ferrer, M. \& Pometta, D. (1985) A noncompetitive enzyme-linked immunosorbent assay for measuring human plasma apolipoprotein B levels. Clin. Chim. Acta $151,317-324$.

Dr. K. Adeli
Department of Chemistry and Biochemistry
University of Windsor
401 Sunset Street
Windsor, Ontario
N9B 3P4
Canada

